\title{
First report of a phytoplasma associated with sapodilla flattened stem disease in Iran
}

\author{
Abdoolnabi Bagheri ${ }^{1}$ • Mohammad Mehdi Faghihi ${ }^{1}$. \\ Hamed Hassanzadeh Khankahdani ${ }^{2}$ - Majeed Askari Seyahooei ${ }^{1}$ - Najibeh Ghanbari $^{1}$. \\ Somayeh Salehi Sarbijan ${ }^{3}$
}

Received: 28 December 2016 / Accepted: 20 April 2017 /Published online: 9 May 2017

(C) Australasian Plant Pathology Society Inc. 2017

\begin{abstract}
Disease symptoms resembling those associated with phytoplasmas were observed in Manilkara zapota (sapodilla) trees in Hormozgan province, Iran. A nested polymerase chain reaction using phytoplasma universal primers was used to detect phytoplasmas in symptomatic trees. Amplification and sequencing of a $1.2-\mathrm{kb} 16 \mathrm{~S}$ rDNA fragment confirmed that sapodilla plants were infected by a phytoplasma belonging to the $16 \mathrm{SrII}$ group.
\end{abstract}

Keywords Fasciation · Little leaf · Manilkara zapota $\cdot 16 \mathrm{SrII}$ phytoplasma group

Manilkara zapota (Sapotaceae), commonly known as sapodilla or chico, is a tropical large evergreen tree, native to Mexico and Central America (Parle and Preeti 2015). This tree species was first introduced to southern Iran (Hormozgan, Sistan \& Baluchestan provinces) in the 1940s. A warmhumid climate and lack of cold winters in the Hormozgan province have encouraged farmers to cultivate tropical fruits such as sapodilla. For the past decade, the sapodilla trees were

Mohammad Mehdi Faghihi

mm.faghihi@yahoo.com

1 Plant Protection Research Department, Hormozgan Agricultural and Natural Resources Research and Education Center, Agricultural Research Education and Extension Organization (AREEO), Bandar Abbas, Iran

2 Horticultural Crops Research Department, Hormozgan Agricultural and Natural Resources Research and Education Center, Agricultural Research Education and Extension Organization (AREEO), Bandar Abbas, Iran

3 Plant Protection Division, Organization of Jahad Agriculture of Jiroft, Jiroft, Iran checked to determine its main pests and diseases status. In February 2015, suspected phytoplasma symptoms of flattened stem, little leaf and internode shortening (Fig. 1) were observed on two sapodilla trees in the campus of Hormozgan Agricultural and Natural Resources Research and Education Center (HANRREC), Bandarabbas, Iran. Several samples of symptomatic leaves and branches were collected from these trees and samples of symptomless trees were also prepared from other sapodilla trees in Minab County. Total DNA was extracted separately from two symptomatic and eight symptomless trees using the CTAB method. Samples were analysed for presence of phytoplasma DNA by direct-PCR using the phytoplasma universal primer pair P1/P7 (Deng and Hiruki 1991; Schneider et al. 1995) and nested-PCR using primer pairs P1/P7 (first round) and R16F2n/R16R2 (second round) (Gundersen and Lee 1996). The PCR was performed in $20 \mu \mathrm{l}$ of reaction mixture containing $10 \mu \mathrm{l}$ PCR Master Mix (Amplicon), $1 \mu \mathrm{l}$ of each primer $(10 \mu \mathrm{M}), 2 \mu \mathrm{l}$ of template DNA and $6 \mu \mathrm{l}$ sterile distilled water. The thermocycling program consisted of an initial denaturation step at $95{ }^{\circ} \mathrm{C}$ for $3 \mathrm{~min}$, followed by 35 cycles of denaturation at $94{ }^{\circ} \mathrm{C}$ for $30 \mathrm{~s}$, annealing at $55^{\circ} \mathrm{C}$ for $40 \mathrm{~s}$ and extension at $72{ }^{\circ} \mathrm{C}$ for $90 \mathrm{~s}$, with a final extension step at $72^{\circ} \mathrm{C}$ for $10 \mathrm{~min}$. The P1/P7 primed PCR product was diluted at 1:10 ratio in sterile water and $2 \mu \mathrm{l}$ was used in nested-PCR as a template. The nestedPCR cycles were the same as for the first round PCR. Direct PCR failed to amplify phytoplasma DNA in all studied samples. However, amplicons of ca. $1.2 \mathrm{~kb}$ were obtained with nested-PCR from the samples of symptomatic but not from symptomless plants and sterile distilled water as negative controls. The positive nested-PCR products were directly sequenced, edited and deposited in GenBank under KY171945 (SFS1) and KY171946 (SFS2) accession numbers. The two 16S rDNA sequences shared $100 \%$ sequence identity with each other. Sequence comparison by BLAST 
Fig. 1 Symptoms of fasciation, little leaf and internode shortening on diseased sapodilla (a) compared with healthy tree (b)
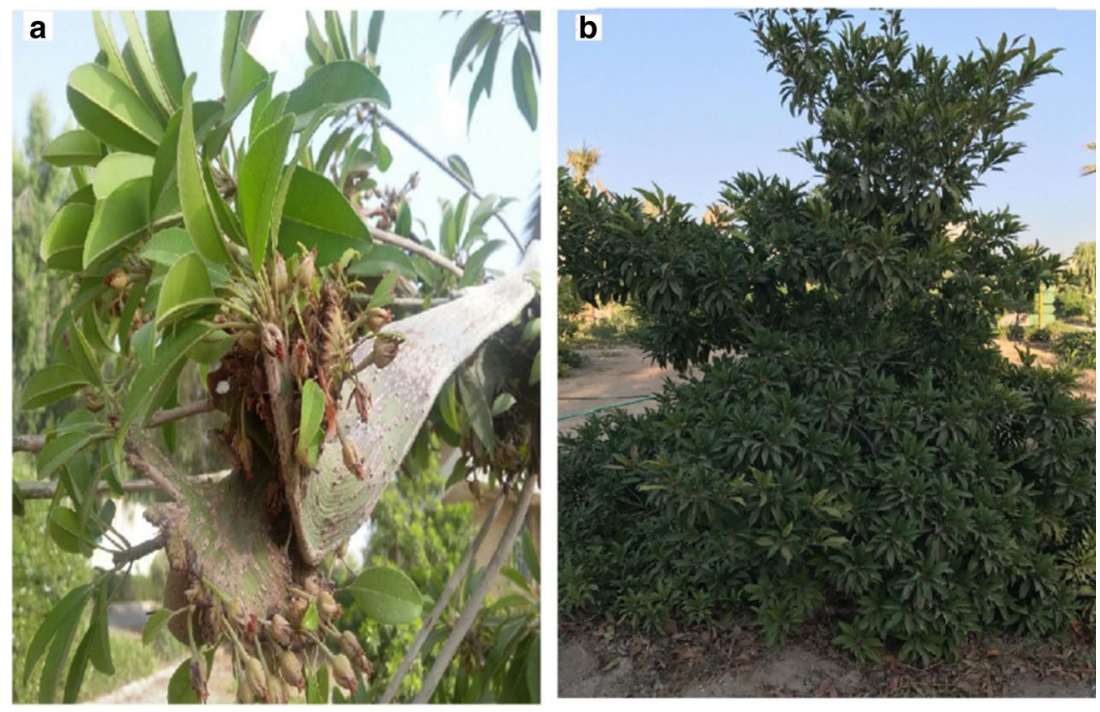

analysis revealed that the two phytoplasma isolates associated with sapodilla flattened stem (SFS), SFS1 (KY171945) and SFS2 (KY171946), had the highest identity (100\%) with several phytoplasma sequences, all belonging to the $16 \mathrm{SrII}$ group (peanut witches' broom group), such as lime witches'broom phytoplasma (EF186828, from Oman), Iranian apple
Fig. 2 Phylogenetic tree of partial 16S rRNA gene sequences from sapodilla flattened stem phytoplasma isolates (marked by a red rectangle) and other phytoplasma sequences belonging to different $16 \mathrm{~S}$ rRNA groups. GenBank accession numbers have been shown for each sequence. Acholeplasma laidlawii was used as outgroup to root the tree. The tree was constructed by the neighbourjoining method using MEGA 5 software

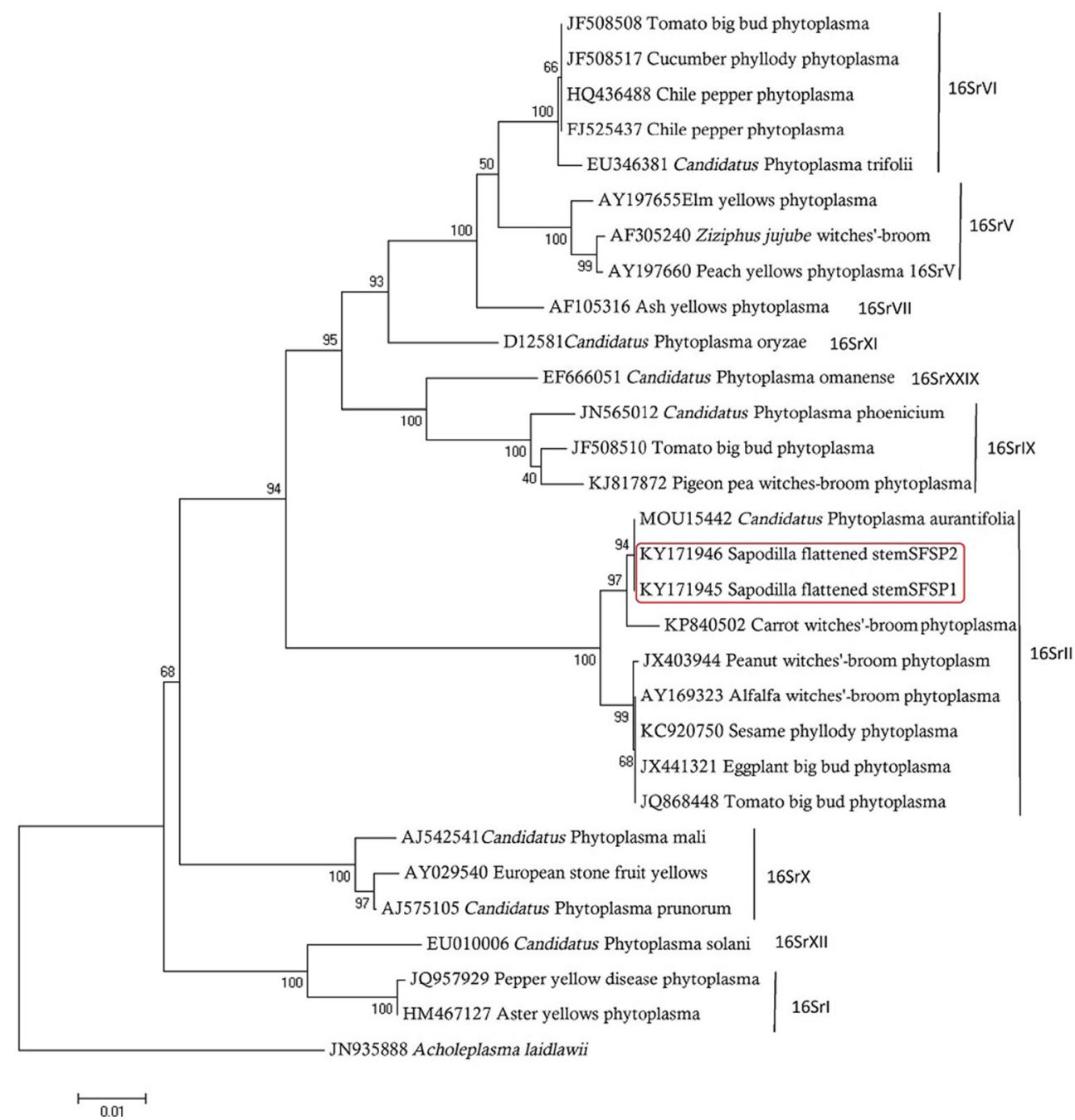


phytoplasma (KC902796, from Iran), grapefruit phytoplasma (JF518980, from Iran) and Hishimonous phycitis phytoplasma (KX828609, from Iran). Phylogenetic analysis using the neighbour-joining method (MEGA 5 software) based on the $16 \mathrm{~S}$ rRNA gene sequences of the phytoplasma isolated from sapodilla and other phytoplasmas demonstrated that the sapodilla flattened stem phytoplasma (SFSP) is a member of the 16SrII phytoplasma clade (Fig. 2).

A phytoplasma, belonging to $16 \mathrm{SrII}$ group, associated with symptoms of leaf yellowing and witches' broom in sapodilla has been observed before in eastern Cuba by Acosta et al. (2008). Furthemore, Pérez-López et al. (2013) detected a $16 \mathrm{SrV}$ phytoplasma associated with witches' broom symptom in sapodilla trees in western Cuba.

In this study, two symptomatic trees observed on the campus of HANRREC in Bandarabbas were positive for phytoplasma. However, none of the samples collected from symptomless trees in Minab County were positive for the presence of phytoplasma. The incidence of sapodilla flattened stem phytoplasma disease in this region can be explained by several potentially factors like planting imported trees with latent infection. Existence of common hemipteran insects with various hosts from different families should not be overlooked. They may transmit phytoplasma from their herbaceous hosts to the sapodilla trees which can be investigated further (Naqvi 2004; Lee et al. 2000; Goldschmidt 2014).

Numerous reports have showed the potential of 16SrIIrelated phytoplasmas to damage the production of various crops in south of Iran. For instance, lime witches' broom phytoplasma has devastated many Mexican lime orchards in these regions. To our knowledge, this is the first report of a $16 \mathrm{SrII}$ phytoplasma associated with sapodilla flattened stem disease in Iran. The flattened stem disease can be a significant warning for sapodilla expansion programs and should be considered in future studies. Biological experiments are underway to expand our understanding in relation to the disease.

Acknowledgements The authors would like to thank Dr. Ramezan Rezazadeh for helpful comments and suggestions to improve the manuscript.

\section{References}

Acosta K, Piñol B, Acosta E, Coutín P, Arocha Y (2008) First report on detection of 'Candidatus Phytoplasma aurantifolia' (group 16SrII) affecting sapodilla in eastern Cuba. Plant Pathol 58:391

Deng S, Hiruki C (1991) Amplification of 16S rRNA genes from culturable and non-culturable mollicutes. J Microbiol Methods 14: 53-61

Goldschmidt EE (2014) Plant grafting: new mechanisms, evolutionary implications. Front Plant Sci 5:727

Gundersen DE, Lee IM (1996) Ultrasensitive detection of phytoplasmas by nested-PCR assays using two universal primer sets. Phytopathol Medit 35:144-151

Lee IM, Davis RE, Gundersen-Rindal DE (2000) Phytoplasmas: Phytopathogenic Mollicutes. Ann Rev Microbiol 54:221-255

Naqvi, SAMH (2004) Diseases of fruits and vegetables. Kluwer Academic Publishers.

Parle M, Preeti (2015) Chickoo: a wonderful gift from nature. Int J res Ayur Pharm 6:544-550

Pérez-López E, Pantoja ML, Hernández-Rodríguez L, Bárzaga IP (2013) First report of a 'Candidatus Phytoplasma ulmi' isolate affecting sapodilla trees in western Cuba. New Dis Rep 28:18

Schneider B, Seemüller E, Smart CD, Kirkpatrick BC (1995) Phylogenetic classification of plant pathogenic mycoplasma-like organisms or phytoplasmas. In: Razin S, Tully JG (eds) Molecular and diagnostic procedures in Mycoplasmology, vol 2. Academic Press, New York, pp 369-380 